\section{Utility of the HEp-2000 antinuclear antibody substrate}

We write with regards to the recently published consensus paper on antinuclear antibody (ANA) staining patterns by Damoiseaux et al which was most informative. ${ }^{1}$ We were surprised, however, that there was no mention or discussion of the HEp-2000 substrate (Immunoconcepts, Sacremento, California, USA) despite the acknowledgement that anti-SS-A/Ro60 is frequently missed on indirect immunofluorescence assay (IIFA). ${ }^{1}$ The HEp-2000 substrate is a modified HEp-2 substrate that is transfected with Ro60 cDNA and hence, over-expresses this antigen. ${ }^{2}$ It produces a bright nuclear/nucleolar staining pattern under IIFA when antiSS-A/Ro60 antibodies are present (figure 1), and is one of the most commonly detected extractable nuclear antigen antibodies. ${ }^{3}$

The HEp-2000 substrate is a sensitive way to detect anti-SS-A/ Ro60 antibodies that may be otherwise missed on conventional immunoassays, such as immunoblotting and the standard HEp-2 substrate. ${ }^{45}$ However, it is not a perfect screen as the HEp-2000 substrate may still miss detection of anti-SS-A/Ro60 sera $^{67}$ indicating that at least a second method for anti-SS-A/Ro60 and other antibody detection is still required. ${ }^{8}$ For other ANA specificities, HEp-2000 performs similarly to the standard HEp-2 substrate with no significant impact on the detection of other ANA fluorescent patterns ${ }^{9}{ }^{10}$ and in fact, improved sensitivities. ${ }^{5}$

It is important to maximise the chances of identifying anti-SS-A/ Ro60, for the antibody, as an example, has significant implications for fertile women for the development of neonatal lupus erythematosus which may have devastating sequelae. ${ }^{11}$ We therefore recommend others to consider the HEp-2000 substrate if employing the IIFA method for ANA detection.

\section{Adrian Y S Lee $\odot$, ${ }^{1}$ Dimitra Beroukas, ${ }^{2}$ Peter J Roberts-Thomson ${ }^{1}$ \\ ${ }^{1}$ Clinical Immunology and Allergy, Flinders Medical Centre, Bedford Park, South Australia, Australia \\ ${ }^{2}$ Immunology, SA Pathology, Bedford Park, South Australia, Australia}
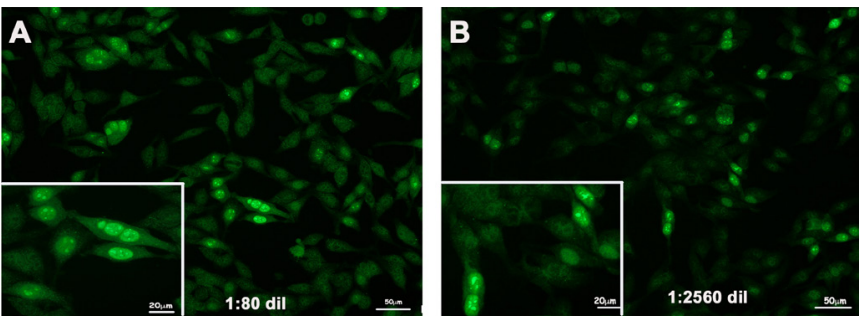

Figure 1 Typical anti-SSA/Ro60 nuclear/nucleolar staining on the HEp2000 substrate using serum specific for anti-Ro60 at (A) 1:80 dilution and (B) 1:2560 dilution. Even with a 32 -fold dilution, the staining is still quite distinct at 1:2560 (B). Insets represent enlarged versions of representative areas on the micrograph.
Correspondence to Dr Adrian Y S Lee, Clinical Immunology and Allergy, Flinders Medical Centre, Bedford Park, South Australia, Australia; adrian.lee2@sa.gov.au

Contributors AYSL drafted the manuscript. DB contributed the figure, provided intellectual content and contributed to the manuscript. PJR-T contributed to the manuscript.

Funding This research received no specific grant from any funding agency in the public, commercial or not-for-profit sectors.

Competing interests None declared.

Patient consent for publication Not required.

Provenance and peer review Not commissioned; internally peer reviewed.

(c) Author(s) (or their employer(s)) 2020. No commercial re-use. See rights and permissions. Published by BMJ.

\section{Check for updates}

To cite Lee AYS, Beroukas D, Roberts-Thomson PJ. Ann Rheum Dis 2020;79:e67.

Received 9 April 2019

Accepted 12 April 2019

Published Online First 14 May 2019

\section{Sinked}

- http://dx.doi.org/10.1136/annrheumdis-2019-215610

Ann Rheum Dis 2020;79:e67. doi:10.1136/annrheumdis-2019-215519

ORCID iD

Adrian Y S Lee http://orcid.org/0000-0002-5179-4803

\section{REFERENCES}

1 Damoiseaux J, Andrade LEC, Carballo OG, et al. Clinical relevance of HEp-2 indirect immunofluorescent patterns: the International consensus on ANA patterns (ICAP) perspective. Ann Rheum Dis 2019;78:879-89.

2 Keech CL, McCluskey J, Gordon TP. Transfection and overexpression of the human 60$\mathrm{kDa}$ Ro/SS-A autoantigen in HEp-2 cells. Clinical Immunology and Immunopathology 1994;73:146-51

3 Wang $\mathrm{K}-\mathrm{Y}$, Yang $\mathrm{Y}-\mathrm{H}$, Chuang $\mathrm{Y}-\mathrm{H}$, et al. The initial manifestations and final diagnosis of patients with high and low titers of antinuclear antibodies after 6 months of follow-up. Journal of Microbiology, Immunology and Infection 2011;44:222-8.

4 Fritzler MJ, Miller BJ. Detection of autoantibodies to ss-a/ro by indirect immunofluorescence using a transfected and overexpressed human $60 \mathrm{kd}$ Ro autoantigen in HEp-2 cells. J. Clin. Lab. Anal. 1995;9:218-24.

5 Kidd K, Cusi K, Mueller R, et al. Detection and identification of significant Anas in previously determined ANA negative samples. Clin Lab 2005;51:517-21.

6 Bossuyt X, Frans J, Hendrickx A, et al. Detection of anti-SSA antibodies by indirect immunofluorescence. Clin Chem 2004;50:2361-9.

7 Choi MY, Clarke AE, St.Pierre Y, et al. Antinuclear antibody-negative systemic lupus erythematosus in an international inception cohort. Arthritis Care Res. 2018.

8 Hoffman IEA, Peene I, Veys EM, et al. Sensitivity of ANA indirect immunofluorescence testing for the detection of anti-ENA antibodies. Arthritis Res 2002;4(Suppl 1).

9 Keech CL, Howarth S, Coates T, et al. Rapid and sensitive detection of anti-Ro (SS-A) antibodies by indirect immunofluorescence of 60kDa Ro HEp-2 transfectants. Pathology 1996:28:54-7.

10 Peene I, Van Ael W, Vandenbossche M, et al. Sensitivity of the HEp-2000 substrate for the detection of Anti-SSA/Ro60 antibodies. Clinical Rheumatology 2000;19:291-5.

11 Lee LA. Cutaneous lupus in infancy and childhood. Lupus 2010;19:1112-7. 